\title{
$\underline{\mathbf{P}-17}$
}

\section{Nutritional Content, Antioxidant and Antibacterial Activities of Litsea Garciae}

\author{
Clifford Junaidi Kutoi, Khong Heng Yen" and Nurr Maria Ulfa Seruji \\ School of Chemistry and Environmental Studies, Faculty of Applied Sciences, University Teknologi MARA (UiTM), \\ 94300 Kota Samarahan, Sarawak, Malaysia; E-mail: khonghy@sarawak.uitm.edu.my
}

In Sarawak, Litsea garciae are known as "Engkala". The tree of 'Engkala' can grow in inland riparian forest and secondary forest. This medium-sized tree have long brittle spreading branches and the leaves lanceolate or obovate often with unequal side (asymmetric) and non-hairy. This seasonal fruit turn pink, or pinkish, greenish white when it is ripping depending on the variety. It is used as antidote against scorpion, centipede and snake bite by Bidayuh and Iban communities. It is also used to treat muscular pains, sprained ankles and knees, skin disease and blood in stools. The metanolic leaves, barks and fruits extracts of L. garciae were tested for its nutritional value, antioxidant and antibacterial activities. The nutritional values, such as $\mathrm{N}$, $\mathrm{P}$, $\mathrm{K}, \mathrm{Ca}, \mathrm{Mg}, \mathrm{Fe}, \mathrm{Mn}, \mathrm{Cu}, \mathrm{Zn}, \mathrm{B}$, moisture, ash, protein, carbohydrates and fat were determined based on MS677 and ICP-AES. The antioxidant assay was carried out using DPPH, free radical scavenging activity while the antibacterial assays were carried out using minimum inhibitory concentration (MIC) and disk diffusion method against five bacteria. The findings showed that $L$. garciae is a good source of carbohydrate and protein. In addition, it is also demonstrated weak activities towards antioxidant and antibacterial. The phytochemistry study on this plant is being carried out to identify bioactive compounds. Preliminary results suggest that $L$. garciae is rich in stearic acid. This common saturated fatty acids derived from plants may be used in the production of biodegradable soaps and cosmetics such as shampoo and shaving cream products.

Keywords: Litsea garciae, Nutritional content, Antioxidant, Antibacterial. 